\title{
Factors Influencing Knowledge Management Practices among Multimedia Super Corridor (MSC) organizations
}

\author{
Yap L S, Rosmaini Tasmin, Muhamad Saufi Che Rusuli, and Norazlin Hashim \\ Universiti Tun Hussein Onn Malaysia, Malaysia
}

\begin{abstract}
Knowledge management (KM) has emerged as a new discipline in managing organization. It plays important roles in establishing long term internal strength and supporting external competitive advantage. The purpose of this study is to gauge the level of KM practices in MSC status organizations. It also shows relationship between demography of respondents with KM influential factors in those organizations. Survey question which consists of 4 main KM influential factors were distributed. Results of 121 data sets have been collected from 4 MSC-status organizations. Mean score and One Way ANOVA are applied to identify the level of KM practices. This also identifies the relation between the demography and KM factors. It is found out that KM practices in MSC status organizations are at medium level. There are significant differences in KM practices with respect to age of respondents and job designation. It can be concluded that sufficient attention should be given to culture, information technology, organization structure and people to achieve success in KM practices.
\end{abstract}

Keywords: Influential factors, Knowledge management, knowledge management practices, MSC status organizations, new discipline

\section{Introduction}

Knowledge management can be defined as the process of transforming information and intellectual assets into enduring value. It connects people with the knowledge that they need to take action. By applying knowledge management into organization, it can integrate, identify, manage and share all of the department's information assets. According to Darroch (2005), knowledge management has emerged as a new discipline in an organization, and it plays an important supporting function by providing a coordinating mechanism to enhance conversion of resources into capabilities. Newman (2000) stated that this knowledge management promotes an integrated approach to identifying, capturing, retrieving, sharing, and evaluating an enterprises information asset. These information assets may include databases, documents, policies, procedures, as well as the uncaptured tacit expertise and experience stored in individual's heads.

\begin{abstract}
Background
Multimedia Super Corridor (MSC) is the Malaysian government initiative. It was designed to leapfrog Malaysia into the information and knowledge age. The MSC was initiated as a part of Malaysia's long term plan to become a knowledge-based and a fully developed country by the year 2020. This corridor houses core MSC initiatives which include high-technology projects such as eGovernment, Telemedicine, Smart School, Multipurpose Smart Card System, Research and Development Cluster, e-Business and Technopreneur Development.
\end{abstract}

Copyright (C) 2010 Yap L S, Rosmaini Tasmin, Muhamad Saufi Che Rusuli, and Norazlin Hashim. This is an open access article distributed under the Creative Commons Attribution License unported 3.0, which permits unrestricted use, distribution, and reproduction in any medium, provided that original work is properly cited. Contact author: Rosmaini Tasmin e-mail: rosmaini@uthm.edu.my 
The MSC is a $50 \times 50 \mathrm{~km} 2$ zone, stretching from the

Petronas Twin Towers (world's tallest towers) in the

center of Kuala Lumpur to the newly built Kuala Lumpur International Airport (KLIA). It comprises several administrative, industrial and technological development clusters. Among the clusters are: (1) Putrajaya, the newly built seat of the federal government, (2) Cyberjaya, an intelligent city which will house multimedia industries as well as research centers and the Multimedia University (MMU), (3) Technology Park Malaysia, a park located in the center of the MSC providing engineering and IT facilities to entrepreneurs, investors and industries. Previous industrial development projects such as the free trade zone in Petaling Jaya, manufacturing hubs in the outskirts of Kuala Lumpur and the city's financial centers also fall within the MSC (Ramasamy, et al., 2004).

The idea of the importance of knowledge management in Malaysia was first expressed by the former Prime Minister, Tun Dr. Mahathir in 1991. He highlighted that there is a need to transform economy of Malaysia towards a knowledge-based economy in order to achieve vision 2020. The common knowledge management approaches in Malaysia was implemented through knowledge management applications in Multimedia Companies such as the one applied at Microsoft Malaysia (KMtalk .net).

\section{Problem Statement}

According to Gan (2006), there is lacking of knowledge management surveys from Malaysian perspectives. Most Malaysians do not understand well about knowledge management and it functions. Furthermore, most companies do not investigate the implementation of knowledge management. The knowledge transfer and knowledge sharing in an organization may be limited if they do not apply appropriate knowledge management approaches.

A survey reported that many top executives of firms view knowledge management resources as critical for a firm's success (Amlus Ibrahim et al. 2006). This implies that many firms are lacking knowledge management strategy in their firms. The success of firms is strongly related with managing knowledge.

Amlus Ibrahim et al. (2006) stated that there is no single department or function alone that can deliver corporate objectives. The shifting winds of change in today's business environment, together with the pressure of the emergence of global knowledge-based economy, have made organizations realize that the knowledge is their key asset (Chong et al., 2006). Without knowledge-based approach, company may face several problems and tougher competition in global market.

Traditional disciplinary knowledge is limited in its ability to support challenging decisions that lie ahead. This causes organizations to have urgent measure for seeking fundamental insight to help them immense potential of their knowledge asset for capability to excel at the leading edge of innovation (Syed Z. Shariq, 1997).

\section{Research Questions}

- What is the level of knowledge management practices among MSC status organizations?

- What is the relationship between demographic elements and knowledge management factors that can influence the implementation of knowledge management practices in MSC status organizations?

\section{Objectives}

- To measure the level of knowledge management practices in MSC status organizations.

- To identify the relationship between demographic elements and knowledge management factors that can influence the implementation of knowledge management practices in those organizations.

\section{Significance of the Research}

The purpose of this study is to provide a clear understanding of knowledge management research. Besides that, this study is to find out the current levels of knowledge management practices among Multimedia Super Corridor companies in Malaysia. It allows better understanding of knowledge management practices in these companies. Apart from that, it also allows organizations to understand all the process which is needed in knowledge management to build appropriate knowledge management strategies for competitive advantage. 


\section{Scope of Research}

This research will be conducted in Pahang, more specifically in the area of Kuantan. Research will be conducted in MSC status organizations in Kuantan. The samples of this research will be carried out on organizations which were registered under the category of MSC-status organizations.

\section{Literature Review}

Subsequent sections highlight the basis of this study such as background of KM, definitions, and theories.

\section{Definitions of Knowledge}

At the fundamental level, knowledge is defined as information possessed by individuals within the organization. We change the information into knowledge form in an individual, and then distribute and sharing the knowledge within the organization. Systems designed to support knowledge may not appear to be radically different from other forms of information systems, but will be aimed towards enabling users to assign meaning to information and to capture their knowledge (Randeree, 2006).

Drucker (1993) describes knowledge as the only meaningful resource in a knowledge society. He further stresses that "...knowledge is not impersonal like money. Knowledge does not reside in a book, a data bank, a software program. They contain only information". Knowledge is always embodied in a person, taught and learned by a person, used or misused by a person (Drucker, 1993, p. 191).

Sharifuddin and Rowland (2004) clearly shown that knowledge transfer, capture and dissemination and organizational knowledge are some of the important elements in knowledge and knowledge management (p. 239).

According to Greiner (2007), knowledge emerges from the processing of the perceived information and contextualization of a person. This shows that knowledge can only exist in the context of person and his beliefs and experience. "Knowledge is a fluid mix of framed experience, values, contextual information, and expert insight that provides a framework for evaluating and incorporating new experiences and information" (Davenport and Prusak, 1998). Thus, knowledge can also be defined as the ability of persons to evaluate information and act efficiently (Sveiby, 1998).
Knowledge can provide added value if it results in actions and decisions (O'Dell and Grayson, 1998).

\section{Types of Knowledge}

People possess slightly different types of tacit and explicit knowledge and apply their knowledge in unique ways. There are two main types of knowledge, namely tacit knowledge and explicit knowledge. Explicit knowledge is formalized and written knowledge, expressed in the form of data, scientific formula, specifications, manuals, or textbooks. It can be articulated, explained, and may sometimes help individual articulate what they know. Smith (2001) explained that most of explicit knowledge is technical or academic data or information that is described in formal language, like manuals, mathematical expressions, copyright and patents. This "know-what," or systematic knowledge is readily communicated and shared through print, electronic methods and other formal means (p. 313). While tacit knowledge is action-based and unformulated, highly personal and hard to transfer. Tacit knowledge is automatic, requires little or no time or thought and helps determine how organizations make decisions and influence the collective behavior of their members (Smith, 2001; Liebowitz and Beckman, 1998).

\section{Definitions of Knowledge Management}

Knowledge management was defined as an organizational capability that allows people in organization working as a individual, or in teams, project, or other such communities of interest, to create, capture, share, and leverage their collective knowledge to improve performance (Lakshman, 2007). By appling knowledge management in organizations, it can increased globalization of competition, speed of information and knowledge aging, dynamics of both product and process innovations, and competition through buyer markets (Greiner et al., 2007).

Malhotra (2005) argued that knowledge management is a function of the generation and dissemination of information, developing a shared understanding of the information, filtering shared understandings into degrees of potential value, and storing valuable knowledge within the confines of an accessible organizational mechanism. Knowledge management systems must connect people to enable them to think together and to take time to articulate and share information and insights they know are useful to others in their community (Josephine Lang C.Y. 2001). 
Rosmaini Tasmin and Woods (2007) argued that, knowledge management as a socio-technologybased system that supports the collaboration and integration among interlocking organizational function to create more innovation and valueadded products and services for the market. According Amlus Ibrahim et al. (2006), knowledge management is a more detailed and 'everyday management approach than intellectual capital management; it focuses on facilitating and managing knowledge-related activities.

\section{SECI Theory}

(Refer to appendix 1)

SECI theory can be expressed as the interaction between tacit and explicit knowledge. According Nonaka and Takeuchi (1995), SECI consist of four different modes of knowledge conversation which is Socialization, Externalization, Combination and Internalization.

\section{Knowledge Management Model}

The Socio-Technical Model

(Refer to appendix 2)

- Infoculture (organizational and social culture in knowledge sharing),

- Infrastructure (technological systems for networked communications), and

- Infostructure (protocols for knowledge exchange and a means to measure).

\section{Lindsey Model}

(Refer to appendix 3)

Lindsey proposed a knowledge management effectiveness model by combining the contingency-perspective theory and the organizational capability perspective theory (Rosmaini Tasmin and Woods, 2008). The knowledge management effectiveness model has two main constructs, namely knowledge infrastructure and knowledge process capabilities (Rosmaini Tasmin and Woods, 2008).

\section{Knowledge Management Framework}

(Refer to appendix 4)

The KM Framework considers three layers as the most important for KM:
a) Business Focus
b) Core Knowledge Activities
c) Enablers

\section{Knowledge Management in Malaysia}

Knowledge management only really began to take off in the late 1990s. Malaysian government through its "Knowledge Economy Master Plan" had inspired government agencies as well as local companies to adopt knowledge management. There is very few Malaysian companies have initiated any knowledge management programs in Malaysia.

Government agencies are among the earliest organizations to initiated knowledge management approaches in Malaysia. Government Linked Companies (GLCs) are in advanced stage in term of knowledge management practices. Only few private companies have taken advanced approach in knowledge management initiatives.

According to some researchers, in order to launch knowledge management successfully, Malaysian companies need to develop strategic perspectives at viewing and sharing knowledge.

\section{Multimedia Super Corridor}

The Malaysian government set up the Multimedia Development Corporation in 1996 to oversee the development of a Multimedia "Super Corridor" (trade zone). The idea was to make Malaysia a major production and service sector for high tech and multimedia industries. By the year 2020, the MSC will be extended to the whole country, transforming Malaysia to a knowledge-based economy and society, as envisaged in Vision 2020.

The Government recognizes local and international companies that undertake ICT activities in the MSC by awarding them with a MSC Status. MSC-status companies enjoy a host of incentives and benefits from the Malaysian Government that is backed by the ten-point Bill of Guarantees. These MSC status companies are actually involved in software development, software design, internet-based solution and content development (MDC).

Knowledge Management Practices in Malaysia One of the earliest studies on knowledge management in Malaysia indicated that Malaysian organizations tend to be slow in uptake of knowledge management and that levels of knowledge management is still in the infancy stage (Goh, 2006). The knowledge sharing among manufacturing was found that at a moderate level, electrical and electronics-based organizations revealed that there is no clear and identifiable 
knowledge management strategy in place (Goh, 2006).

There are several causes that influence the implementation of knowledge management practices in Malaysia. According to Goh (2005), the primary challenge faced by organizations in Malaysia is changing the employees' behavior and practices. Organizations in Malaysia tend to be highly bureaucratic and have a centralized decision-making structure with lower levels of knowledge management applications and system in place (Ramanathan Narayanan et al., 2003).

\section{Issues in Knowledge Management \\ - Cultural Issue}

According Suresh and Egbu (2004), organisational culture is an important factor to consider in the context of KM, as its boundaries may often restrict the flow of information and knowledge among employees. Gupta and Govindarajan (2000) described a social environment as a social system, or organisational culture, in which people operate.

- Who Should Share What Issues

Suresh and Egbu (2004) stated that in making knowledge available and usable across the whole organisation, the critical questions are: Who should know what, to what level of detail, and how can the organisation support these processes of knowledge sharing? This is because not everyone needs to know everything.

\section{- Technological Issues}

Technology can make the exchange of knowledge become faster, easier, and smoothly.

\section{- Leadership Issue}

Asoh et al. (2002) concluded that the success of any organization depends on leadership and the success of any leader depends on his/her assigned roles and how the roles are performed.

\section{- Security, Privacy and Standards Issues}

Suresh and Egbu (2004) argued that, identifying and locating experts, knowing what organizations and individuals know, and knowledge sharing have significant security and privacy implications. Standards play a significant role which is includes agent communication, meta-data representation, business integration, interoperability, multichannel and cross-channel success, portals, and advanced collaboration (Satyadas and Harigopal, 2001).

\section{Challenge of Knowledge Management}

- Management Challenge

Management involves having the right leader doing the right activities to provide the thorough analysis of the status quo and the appropriate changes that will improve the system and yield good results (Stukalina, 2006).

\section{- Economic Challenge}

Information and knowledge products seem to be governed by a different law of economic return: investment in every additional unit of information or knowledge created and utilized could result in progressively higher returns (Suresh and Egbu 2004).

\section{- Implementation Challenge}

According to Bygstad (2008), Kwon and Zmud argued that Implementation is mostly seen as an acceptance. The spread of the knowledge-based, less hierarchical organizations with both more powerful and knowledgeable user has accelerated this development.

\section{Influencing Factors \\ - Culture}

According Rosmaini Tasmin and Woods (2007), knowledge culture constitutes of the accumulation and combination of common expectation, tacit rules, shares experiences and social norms that shape our attitudes and behaviors. Successful organizations empower employees to want to share and contribute intellectual information, by rewarding them for such actions (Mathi, 2004).

\section{- Informational technology}

According Chourides et al. (2003), Ruggles and Leug argued that knowledge building is dependent upon IT. In order to build knowledge sharing capabilities, the organization must develop a comprehensive infrastructure that facilitates the various types of knowledge and communication (Kim and Lee, 2004).

\section{- Organization Structure}

Gan (2006) articulated that the structure of the organization impacts the ways in which organizations conduct their operations and in doing so, affects how knowledge is created and shared amongst employees. The hierarchical structure of an organization affects the people with whom individuals frequently interact, and to 
or from whom they are consequently likely to transfer knowledge (Wei et al., 2006).

\section{- People}

Goh (2006) articulated that people are the heart of creating organizational knowledge as it is people who create and shared knowledge. People are said to be true agents in business where all tangible and intangible assets are result of human action and depend ultimately on people for their continued existence (Syed Omar Sarifuddin and Rowland, 2004).

\section{Methodology and Research Design}

According Chua (2006), the outcome of research is determined by method and the research design. While the research design is determined by the objective of the research. In this research, a quantitative research methodology will be used. Chua (2006) stated that not all the research designs can be used in all the research, but a research can use several types of research design (Chua, 2006). There are two types of research, which are experimental and non-experimental. This research will apply non-experimental research design.

\section{Sampling}

Sampling is a process of choosing a number of subjects from a population to become research respondents (Chua, 2006). According Saunders et al. (2007), sampling technique provide a range of method that enable research to reduce the amount of data need to collect by considering only data from a subgroup rather than all possible cases or elements. There have two types of sampling method which is probability sampling and nonprobability sampling (Saunders et al., 2007). In this research, the sampling method will be use is non-probability sampling. Non-probability sampling provides a range of alternative techniques to select samples based on subjective judgement (Saunders et al., 2007).

\section{Sampling Method}

The sampling method in this research is nonprobability sampling. The technique will be choosing is purposive sampling. Purposive sampling is a sampling which is a group of respondents will be choose have same characteristic and enable answer research question and meet the objective.

\section{Research Population and Research Sample}

The population of this study will be the employees in Multimedia Super Corridor (MSC) Status organizations. The sample of this study is the employees in the Multimedia Super Corridor (MSC) Status Companies in Kuantan. While the target respondents in this research are knowledge-based workers and academic staffs. In this research, the total number population is 340 people and the size sample is 180 people.

\section{Research Instrument}

Research instrument is a tool that specially to collect data for the research. The method data collection use in this research is survey.

\section{Survey}

The survey question will distribute randomly to the employees of MSC status companies in Kuantan. The survey will be divided into two parts. The first part of survey is the personal information of the respondents. The second part of the survey is the questionnaire of the critical success factors to be defined with the Likert-scale.

\section{Data Analysis}

- Reliability and Validity

- Descriptive Analysis

- One Way ANOVA

Table 1: Reliability Test Analysis

\begin{tabular}{|l|l|l|l|}
\hline Factors & $\begin{array}{l}\text { Cronbach's } \\
\text { Alpha }(\boldsymbol{\alpha})\end{array}$ & $\begin{array}{l}\text { No. } \\
\text { of } \\
\text { Item }\end{array}$ & $\begin{array}{l}\text { No. of } \\
\text { Respondent }\end{array}$ \\
\hline Cultural & 0.779 & 10 & 121 \\
\hline $\begin{array}{l}\text { Information } \\
\text { Technology }\end{array}$ & 0.857 & 7 & 121 \\
\hline $\begin{array}{l}\text { Organization } \\
\text { Structure }\end{array}$ & 0.834 & 6 & 121 \\
\hline People & 0.852 & 13 & 121 \\
\hline Total & 0.929 & 36 & \\
\hline
\end{tabular}

\section{Feedback Rate}

180 sets of questionnaires have been distributed to employees and knowledge-based worker in Cosmopoint College, OPEN University, UMP, and IKIP College. The total set of questionnaires that have been collected is 121 sets which is equivalent to $67.2 \%$, while, 59 sets of questionnaire cannot be collect because the researcher has distributed the questionnaires during the semester break when most of the employees were on holiday. 


\section{Demographic Analyses}

The subsequent section reports the basic findings of the research in terms of demographics of respondents. It consists of respondents' age, gender, designation, number of years working in current firms, overall working experience, and familiarity with KM.

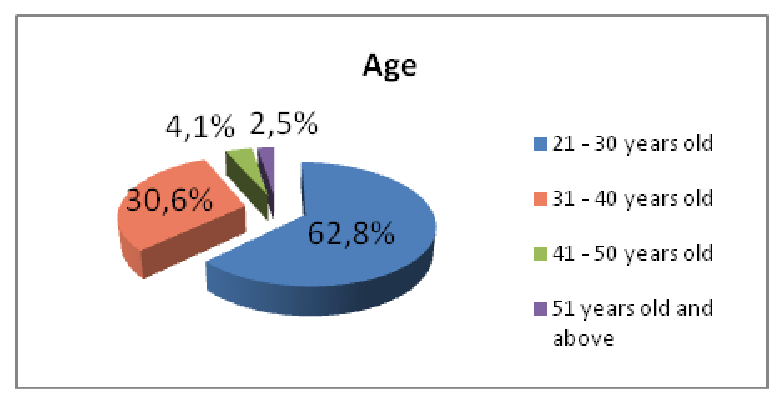

Fig. 1: Respondent Age Distribution

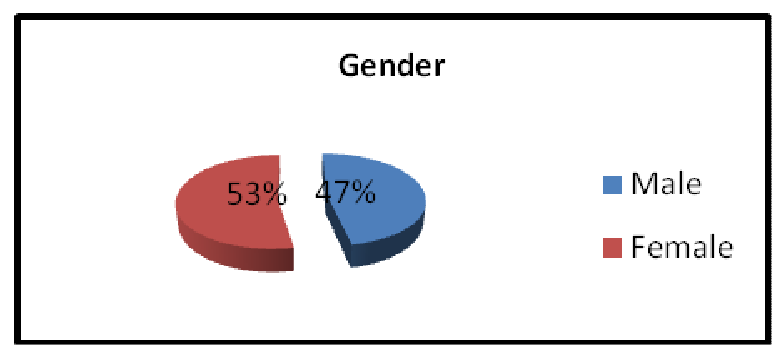

Fig. 2: Respondent Gender Distribution

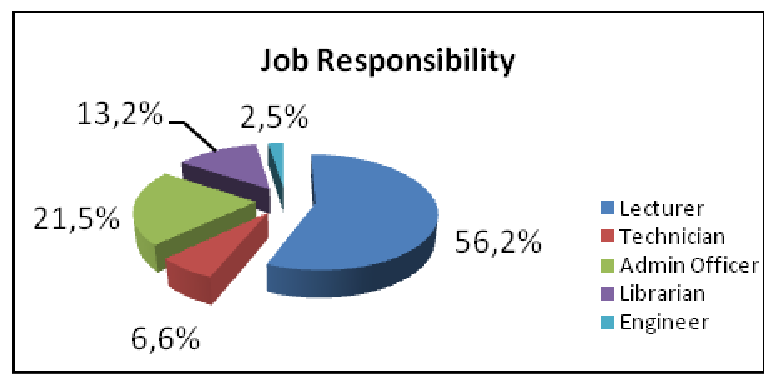

Fig. 3: Respondent Job Responsibility Distribution

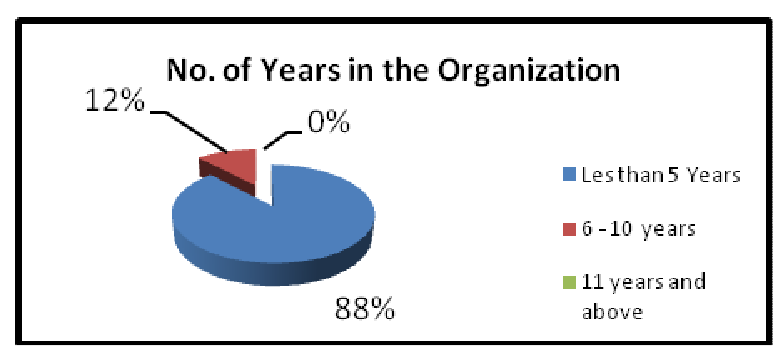

Fig. 4: Distribution of Number of Years in the Organization

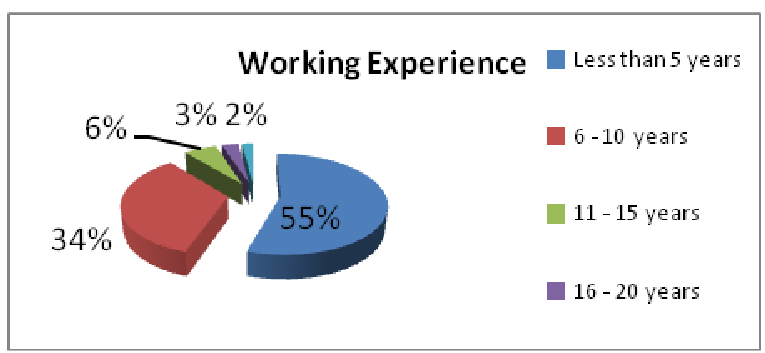

Fig. 5: Respondent Working Experience Distribution

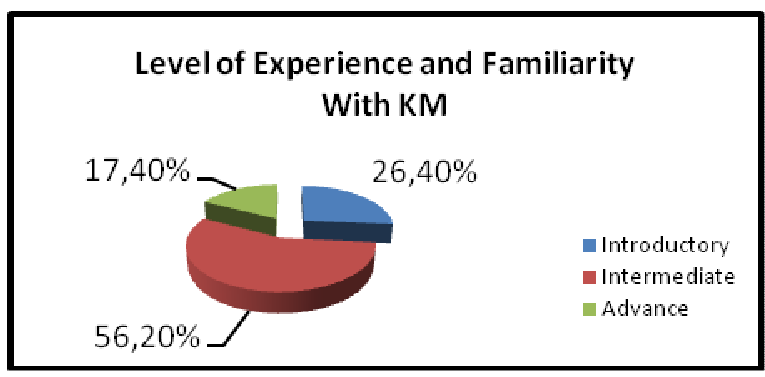

Fig. 6: Level of Experience and Familiarity with KM Distribution

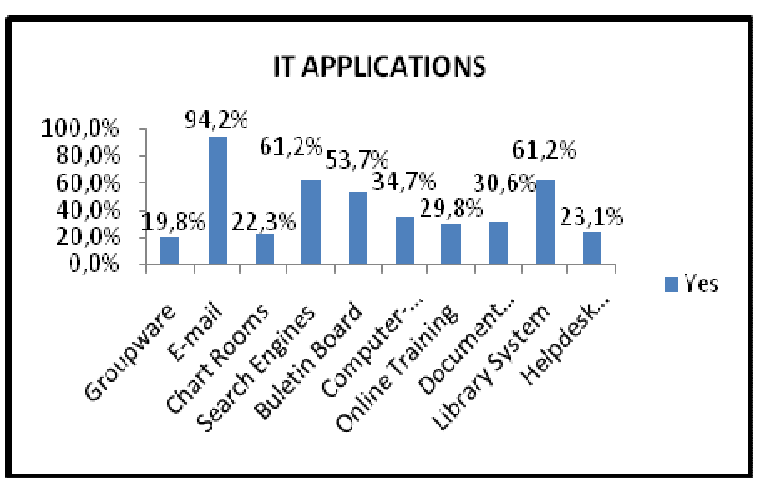

Fig. 7: IT Application Distribution

Table 2: Extent Level for Each Knowledge Management's Factors

\begin{tabular}{|l|l|l|l|}
\hline Factors & Mean & $\begin{array}{l}\text { Std } \\
\text { Deviation }\end{array}$ & Extent \\
\hline Culture & 3.5033 & 0.47363 & Medium \\
\hline $\begin{array}{l}\text { Informational } \\
\text { Technology }\end{array}$ & 3.6883 & 0.54242 & Medium \\
\hline $\begin{array}{l}\text { Organization } \\
\text { Structure }\end{array}$ & 3.4411 & 0.57521 & Medium \\
\hline People & 3.5149 & 0.48669 & Medium \\
\hline Overall & 3.5381 & 0.42649 & Medium \\
\hline
\end{tabular}


Table 4: demographic information

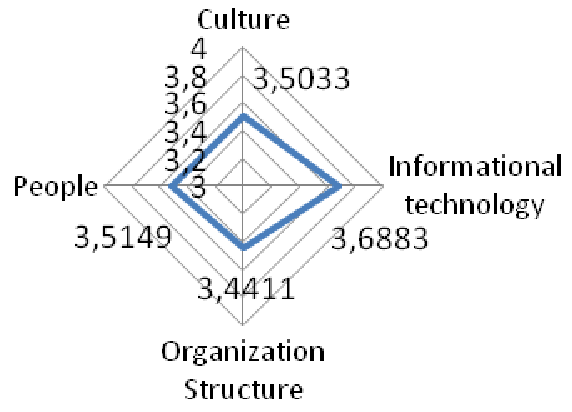

Fig. 8: KM Radar Chart

\section{Normality Test}

Table 3: One-Sample Kolmogorov-Smirnov Test

\begin{tabular}{|lc|l|}
\hline & & Total \\
\hline $\mathrm{N}$ & & 121 \\
Normal Parameters & Mean & 3.5381 \\
& Std. Deviation & 0.42649 \\
Most Extreme & Absolute & 0.089 \\
Differences & Positive & 0.089 \\
& Negative & -0.056 \\
Kolmogorov-Smirnov Z & 0.983 \\
Asymp. Sig. (2-tailed) or P & 0.289 \\
\hline
\end{tabular}

Test Distribution is Normal

One Way ANOVA Analysis to Test the Relationship between KM Influencing Factor and Organization Demography

The organization demography included age of respondent, number of years in the organization of respondent, working experience of respondent, and job designation of respondent. The significant value in One Way ANOVA is $0.05(5 \%)$. For any values more than 0.05 , it means that the variables have no significant difference. On the other hand, if the value is less than 0.05 , it means that the variables have significant differences between the dependent list and factor.

\begin{tabular}{|l|l|l|l|}
\hline Age & Numbers & Mean & $\begin{array}{l}\text { Std. } \\
\text { Deviation }\end{array}$ \\
\hline $\begin{array}{l}21-30 \\
\text { years old }\end{array}$ & 76 & 3.5263 & 0.52638 \\
\hline $\begin{array}{l}31-40 \\
\text { years old }\end{array}$ & 37 & 3.4369 & 0.61281 \\
\hline $\begin{array}{l}41-50 \\
\text { years old }\end{array}$ & 5 & 3.4333 & 0.67289 \\
\hline $\begin{array}{l}51 \text { years } \\
\text { old and } \\
\text { above }\end{array}$ & 3 & 2.5556 & 0.63099 \\
\hline Total & 121 & 3.4711 & 0.57521 \\
\hline
\end{tabular}

Table 5: One Way ANOVA

\begin{tabular}{|l|l|l|l|l|l|}
\hline & $\begin{array}{l}\text { Sum of } \\
\text { Square } \\
\text { s }\end{array}$ & df & $\begin{array}{l}\text { Mean } \\
\text { Squar } \\
\text { e }\end{array}$ & F & f \\
\hline $\begin{array}{l}\text { Betwee } \\
\text { n } \\
\text { Groups }\end{array}$ & 2.797 & 3 & 0.932 & $\begin{array}{l}2.95 \\
5\end{array}$ & $\begin{array}{l}0.03 \\
5\end{array}$ \\
\hline $\begin{array}{l}\text { Within } \\
\text { Groups }\end{array}$ & 36.908 & $\begin{array}{l}11 \\
7\end{array}$ & 0.315 & & \\
\hline Total & 39.704 & $\begin{array}{l}12 \\
0\end{array}$ & & & \\
\hline
\end{tabular}

Comparison of Relationship between Age and Element in Organization Structure (There is significant different)

Table 6

\begin{tabular}{|l|l|l|l|}
\hline $\begin{array}{l}\text { Job } \\
\text { Designation }\end{array}$ & Numbers & Mean & $\begin{array}{l}\text { Std. } \\
\text { Deviation }\end{array}$ \\
\hline Lecturer & 68 & 3.3941 & 0.41641 \\
\hline Librarian & 16 & 3.4437 & 0.32653 \\
\hline Technician & 8 & 3.6125 & 0.34821 \\
\hline $\begin{array}{l}\text { Admin } \\
\text { Officer }\end{array}$ & 26 & 3.7462 & 0.62816 \\
\hline Engineer & 3 & 3.9000 & 0.10000 \\
\hline Total & 121 & 3.5033 & 0.47363 \\
\hline
\end{tabular}


Table 7: One Way ANOVA

\begin{tabular}{|l|l|l|l|l|l|}
\hline & $\begin{array}{l}\text { Sum of } \\
\text { Square } \\
\text { s }\end{array}$ & df & $\begin{array}{l}\text { Mean } \\
\text { Squar } \\
\text { e }\end{array}$ & F & f \\
\hline $\begin{array}{l}\text { Betwee } \\
\text { n } \\
\text { Groups }\end{array}$ & 2.968 & 4 & 0.742 & $\begin{array}{l}3.59 \\
4\end{array}$ & $\begin{array}{l}0.00 \\
8\end{array}$ \\
\hline $\begin{array}{l}\text { Within } \\
\text { Groups }\end{array}$ & 23.950 & $\begin{array}{l}11 \\
6\end{array}$ & 0.206 & & \\
\hline Total & 23.950 & $\begin{array}{l}12 \\
0\end{array}$ & & & \\
\hline
\end{tabular}

Comparison of Relationship between Job

Designation and Element in Culture (There is significant different)

Table 8

\begin{tabular}{|l|l|l|l|}
\hline $\begin{array}{l}\text { Job } \\
\text { Designation }\end{array}$ & Numbers & Mean & $\begin{array}{l}\text { Std. } \\
\text { Deviation }\end{array}$ \\
\hline Lecturer & 68 & 3.6092 & 0.51751 \\
\hline Librarian & 16 & 3.7857 & 0.42378 \\
\hline Technician & 8 & 3.7500 & 0.23844 \\
\hline $\begin{array}{l}\text { Admin } \\
\text { Officer }\end{array}$ & 26 & 3.7033 & 0.65143 \\
\hline Engineer & 3 & 4.6667 & 0.29738 \\
\hline Total & 121 & 3.6883 & 0.54242 \\
\hline
\end{tabular}

Table 9: One Way ANOVA

\begin{tabular}{|l|l|l|l|l|l|}
\hline & $\begin{array}{l}\text { Sum of } \\
\text { Square } \\
\text { s }\end{array}$ & df & $\begin{array}{l}\text { Mean } \\
\text { Squar } \\
\text { e }\end{array}$ & F & f \\
\hline $\begin{array}{l}\text { Betwee } \\
\text { n } \\
\text { Groups }\end{array}$ & 3.485 & 4 & 0.871 & $\begin{array}{l}3.17 \\
6\end{array}$ & $\begin{array}{l}0.01 \\
6\end{array}$ \\
\hline $\begin{array}{l}\text { Within } \\
\text { Groups }\end{array}$ & 31.821 & $\begin{array}{l}11 \\
6\end{array}$ & 0.274 & & \\
\hline Total & 35.306 & $\begin{array}{l}12 \\
0\end{array}$ & & & \\
\hline
\end{tabular}

Comparison of Relationship between Job

Responsibility and Element in Information

Technology (There is significant different)
Table 10: Summary of ' $f$ ' Value of One Way ANOVA

\begin{tabular}{|c|c|c|c|c|}
\hline & Age & $\begin{array}{c}\text { No. of } \\
\text { Years in } \\
\text { the } \\
\text { Organiz } \\
\text { ation } \\
\end{array}$ & $\begin{array}{c}\text { Worki } \\
\text { ng } \\
\text { Experi } \\
\text { ence }\end{array}$ & $\begin{array}{c}\text { Job } \\
\text { Design } \\
\text { ation }\end{array}$ \\
\hline Culture & $\begin{array}{c}0.689 \\
\text { Not } \\
\text { Signifi } \\
\text { cant }\end{array}$ & $\begin{array}{c}0.931 \\
\text { Not } \\
\text { Significa } \\
\text { nt }\end{array}$ & $\begin{array}{c}0.313 \\
\text { Not } \\
\text { Signific } \\
\text { ant } \\
\end{array}$ & $\begin{array}{c}0.008 \\
\text { Signific } \\
\text { ant }\end{array}$ \\
\hline $\begin{array}{l}\text { Informa } \\
\text { tion } \\
\text { Technol } \\
\text { ogy }\end{array}$ & $\begin{array}{c}0.795 \\
\text { Not } \\
\text { Signifi } \\
\text { cant }\end{array}$ & $\begin{array}{c}0.70 \\
\text { Not } \\
\text { Significa } \\
\text { nt }\end{array}$ & $\begin{array}{c}0.944 \\
\text { Not } \\
\text { Signific } \\
\text { ant }\end{array}$ & $\begin{array}{c}0.016 \\
\text { Signific } \\
\text { ant }\end{array}$ \\
\hline $\begin{array}{l}\text { Organiz } \\
\text { ation } \\
\text { Structur } \\
\text { e }\end{array}$ & $\begin{array}{c}0.035 \\
\text { Signifi } \\
\text { cant }\end{array}$ & $\begin{array}{c}0.975 \\
\text { Not } \\
\text { Significa } \\
\text { nt }\end{array}$ & $\begin{array}{c}0.061 \\
\text { Slightly } \\
\text { Signific } \\
\text { ant }\end{array}$ & $\begin{array}{c}0.075 \\
\text { Slightly } \\
\text { Signific } \\
\text { ant }\end{array}$ \\
\hline People & $\begin{array}{c}0.679 \\
\text { Not } \\
\text { Signifi } \\
\text { cant }\end{array}$ & $\begin{array}{c}0.353 \\
\text { Not } \\
\text { Significa } \\
\text { nt }\end{array}$ & $\begin{array}{c}0.231 \\
\text { Not } \\
\text { Signific } \\
\text { ant }\end{array}$ & $\begin{array}{c}0.154 \\
\text { Not } \\
\text { Signific } \\
\text { ant }\end{array}$ \\
\hline
\end{tabular}

Discussions, Suggestion and Conclusion

From the findings in the previous chapter, it shows that the level of knowledge management in MSC status organization in Kuantan were of medium range. According Chong et al. (2006), there are many organizations have just started implement knowledge management initiatives. However, they are not aware of the whole spectrum of knowledge management implementation.

Another reason that may lead the knowledge management level of this study to be in the medium range is because of human behavior. Lee and Fariza Hanum (2008) stated that Malaysians do not seem to practice sharing of knowledge in their environment. Malaysians tend to keep their knowledge to themselves rather than sharing it with another person. Besides that, the reason knowledge management in Malaysia is not that successful is due to the fact that most of the Malaysians are quite self-centered or indulge in Chinese-man culture. Most of the people do not teach their skills to another person as they are scared that once they teach their specific skills to the other person, they will lose their specialty.

Communication can also be the factor that influences knowledge sharing in Malaysia. 
Language is one of the tools for communication. The usage of different languages when communicating with another person may cause a problem in the sharing of knowledge.

Apart from that, most of the people do not share their knowledge in order to avoid from being asked by people.

Some other reason that may be linked to knowledge management in Malaysia to be placed in the medium stage the idea of inferiority complex. In comparison with their western friends, Malaysians is not outgoing, hardly proactive and they commonly feel inferior to those from advanced nations. They are afraid that their knowledge might not accurate enough to share. They are scared that once they share their knowledge, others may find fault in it and label him or her as wrong.

When someone regards themselves as not computer savvy, it might serve as a barrier for these people to share their knowledge. The most important tool for knowledge management is information technology. If the person is not computer savvy, is hard for the person to share his or her knowledge by using computers.

The above are few reasons or barriers that lead to the knowledge sharing is not very success in Malaysia. To ensure the success of the implementation of knowledge management in Malaysia, organizations must develop ways to share their knowledge. Improving the efficiency of knowledge sharing is a highly desirable goal because it offers a promise of compounded returns as the organization works harder and smarter.

The second objective of this study is to find out the relationship between demography factors and knowledge management influential factors that can influence the implementation of knowledge management practices in MSC status organizations in Kuantan. From table 4.25 in Chapter IV, it shows that job designation of respondent is the most important demography factors that can influence the implementation of knowledge management practices and it is followed by age of respondent.

From that table, job designation has significant relationship with culture and information technology. There is a significant difference between job designation of respondent and culture, because, respondent with different job designation has different thinking pattern regarding sharing of knowledge. For example, lecturer is the one whom teach or share their knowledge with student. Thus, lecturer is the one whom have the culture to share with everyone.

On the other hand, there is a significant difference between job designation of respondent and information technology infrastructure. This happened because the use of information technology strongly depends on the type of work.

From the same table, there is also significant difference between age of respondent and organization structure. This occurred because top posts in an organization are usually held by older and knowledgeable workers. Organization structure can influence top and bottom employees to share their knowledge among each other.

The successful of knowledge management practices are strongly depend on human behavior. If there is some members in the organization do not cooperate in term of sharing their knowledge, no matter how good and how strong are their information technology, culture, organization structure and the people, the knowledge management is cannot be success. In order to make sure knowledge management can be successfully implemented, all the members in the organization must work together to achieve it.

\section{Limitation of the Study}

There are several limitations from this study when researcher decided to conduct this study. First, the number of responses obtained from the survey was small. The second limitation of this study is that it has primarily focused on knowledge management practices in higher education institutions. The findings obtained may be not clear to represent the knowledge management practices in all MSC status organizations. The third limitation faced when conducting this study is the time constrain. The time given to accomplish this study is too short involving only around seven months. Lack of adequate time given to accomplish this study may cause the findings or results to be affected or not in its ideals.

\section{Suggestion}

Suggestion can be used to improve organizational operation and can be beneficial to future researchers. From the findings and discussion, few suggestions were proposed. The first suggestion 
proposed is that the future researcher can increase the scope of study so that the future findings and results are more accurate. The second suggestion proposed for future researcher is to focus on different fields; not only focused solely on one field so that the future findings can cover all the entire population.

\section{Conclusion}

As a conclusion, the current knowledge management level among MSC status organization in Kuantan is in the medium range and the most important factor ranked is information technology which is identical to the findings of Syed Omar and Rowland (2004). It also shows that there is relationship between some demography factors and knowledge management factors which is represented by the relationship between job designation with culture and information technology and the relationship between age and organization structure. To have successful knowledge management in an organization, one must see it as a total. Although information technology plays an important role in knowledge sharing in an organization, without proper attention paid to culture, organization structure and people, knowledge sharing in an organization cannot be successfully implemented. Thus, information technology, culture, organization structure and people should always be taken into considerations.

\section{Reference}

Amlus Ibrahim, Hirun Azaman Ismail, Susita Hj. Asree, Mohd Radzai Said (2006). "Knowledge Management as Strategy For K-Economy: Looking At Malaysia Environment." Universiti Utara Malaysia. Unpublished.

Asoh, D., Belardo, S. and Neilson, R. (2002). "Knowledge Management: Issues, Challenges and Opportunities for Governments in the New Economy." Proceedings of the 35th Hawaii International Conference on System Sciences. Unpublished.

Bygstad, B. (2008). "Some Implementation Challenges of Knowledge Management Systems: A CRM Case Study." In Murray, E. J. "Knowledge management concepts, methodologies, tools, and applications." New York: Information Science Reference. pp.2334-2344.

Chua, Y. P. (2006). "Research Method.” Malaysia: McGraw-Hill Companies.
Chong, C. W., Chong, S. C., Paul Heng, P. Y. (2006). "KM Implementation in Malaysian Telecommunication Industry." Industry Management \& Data System. Vol.106 No.8. pp.1112-1132.

Chouride, P., Longbottom, D., and Murphy, W. (2003). "Excellence in knowledge management: an empirical study to identify critical factors and performance measures." Measuring Business Excellence. Vol.7. No.2. pp.29-45.

Darroch, J. (2005). "Knowledge Management, Innovation and Firm Performance." Journal of Knowledge Management. Vol.9 No.3. pp.101-115.

Drucker, P.F. (1993), Post-Capitalist Society, Butterworth-Heinemann, Oxford.

Gerald Goh Guan Gan (2006). "Knowledge Management Practices in Multimedia Super Corridor Status Companies In Malaysia." University Of Southern Queensland: Thesis Paper.

Greiner, M. E., Böhmann, T., Krcmar, H. (2007). “A Strategy for Knowledge Management." Journal of Knowledge Management., Vol.11 No.6. pp.3-15.

Gupta, A. K. and Govindarajan, V. (2000). "Knowledge Management's Social Dimension: Lessons From Nucor Steel." Sloan Management Review. 42(1), pp.71-81.

Josephine Lang C. Y. (2001). "Managerial Concerns in Knowledge Management." Journal Of Knowledge Management. Vol.5 No.1. pp.43-57.

Kim, S. H. and Lee, H. S. (2004). “Organizational Factors Affecting Knowledge Sharing Capabilities in E-Government: An Empirical Study." Unpublished.

Lakshman, C. (2007). "Organizational Knowledge Leadership: A Grounded Theory Approach." Leadership \& Organization Development Journal. Vol.28 No.1. pp.51-75.

Lee Ai Leng and Fariza Hanum Md Nasaruddin. (2008). "Application of Knowledge Management in Malaysian Banks -A Pre-liminary Study." Faculty of Computer Science and Information Technology, University Malaya. 
Leibowitz, J., Beckman, T. (1998), Knowledge Organizations: What Every Manager Should Know, CRC Press, Boca Raton, FL., .

Malhotra Y. (2005). "Integrating Knowledge Management Technologies in Organizational Business Processes: Getting Real Time Enterprises to Deliver Real Business Performance." Journal of Knowledge Management. Vol. 9 No.1. pp.7-28.

Newman, W. B. (2000). Knowledge management research and end User work environments 2010. INSPEL, 34(2), pp. 76-79

Nonaka, I. and Takeuchi, H. (1995). "The Knowledge-Creating Company." Oxford: Oxford University Press.

Ramanathan Narayanan, Richardson, S. and Abdul Latif Salleh. (2003). "Knowledge Management: A Malyasian Study". Malaysian Management Review. pp.79-87.

Ramasamy et al. (2004). Malaysia's leap into the future: an evaluation of the multimedia super corridor. Technovation, 24, pp. 871-883.

Randeree, E. (2006). "Knowledge Management: Securing the Future." Journal of Knowledge Management. Vol.10 No.4. pp.145-156.

Rosmaini Tasmin and Woods, P. C. (2007). "Relationship Between Corporate Knowledge Management and The Firm's Innovation Capability." International Journal of Technology and Management. Vol.8 No.1. pp.62-79.

Rosmaini Tasmin and Woods, P. C. (2008). "Knowledge Management Theories and Practices: An Empirical Survey." Proceedings in KMO2008 Conference: Challenges of Knowledge Management, Va'asa, Finland.

Satyadas, A. and Harigopal, U. (2001). "Knowledge Management Tutorial: An Editorial Overview." IEEE Transactions on Systems, Man, and Cybernetics. Vol.31 No.4. pp.429-437.

Saunders, M., Lewis, P. and Thornhill, A. (2007), "Research Methods for Business Students", Prentice Hall.

Smith, E. A. (2001). Knowledge workers; Information resources management; Motivation. Journal of Knowledge Management, 5(4), pp. 311321.
Stukalina, Y. (2006). "New Challenges For The Educational Management in The Knowledgebased Society." Computer Modelling and New Technologies. Vol.10. No.2. pp.26-29.

Suresh, R. H. and Egbu, C. O. (2004). "Knowledge Management: Issues, Challenges And Benefits For A Sustainable Urban Enviroment."Leeds Metropolitan University. Unpublished.

Syed Omar Sharifuddin Syed-Ikhsan and Rowland, F. (2004). "Knowledge Management in A Public Organization: A Study On The Relationship Between Organizational Elements and The Performance of Knowledge Transfer." Journal of Knowledge Management. Vol.8 No.2. pp.95-111.

Syed Z. Shariq (1997). "Knowledge Management: An Emerging Discipline." The Journal of Knowledge Management. Vol.1 No.1. pp.75-82.

Wei, C. C., Choy, C. S. and Paul Yeow, H. P. (2006). "KM Implementation In Malaysian Telecommunication Industry." Industrial Management \& Data System. Vol.106 No.8. pp.1112-1132.

http://www.kmtalk.net/article.php?story $=20050$ $401235019162(27 / 07 / 08)$ 